\title{
SIBNET - SIBERIAN GLOBAL NAVIGATION SATELLITE SYSTEM NETWORK: CURRENT STATE
}

\section{Yu.V. Yasyukevich}

Institute of Solar-Terrestrial Physics SB RAS, Irkutsk, Russia,yasukevich@iszf.irk.ru

\section{A.M. Vesnin}

Institute of Solar-Terrestrial Physics SB RAS,

Irkutsk, Russia,artem_vesnin@iszf.irk.ru

\author{
N.P. Perevalova \\ Institute of Solar-Terrestrial Physics SB RAS, \\ Irkutsk,Russia,pereval@iszf.irk.ru
}

\begin{abstract}
In 2011, ISTP SB RAS began to deploy a routinely operating network of receivers of global navigation satellite system signals. To date, eight permanent and one temporal sites in the Siberian region are operating on a regular basis. These nine sites are equipped with 12 receivers. We use nine multi-frequency multisystem receivers of Javad manufacturer, and three specialized receivers NovAtel GPStation-6 designed to measure ionospheric phase and amplitude scintillations. The deployed network allows a wide range of ionospheric studies as well as studies of the navigation system positioning quality under various heliogeophysical
\end{abstract}

conditions. This article presents general information about the network, its technical characteristics, and current state, as well as the main research problems that can be solved using data from the network.

Keywords: ionosphere, GNSS, GPS, GLONASS, Beidou, total electron content, scintillations, Javad, NovAtel.

\section{INTRODUCTION}

In the last twenty years, global navigation satellite systems (GNSS) have become an essential part of human economic (sensu lato) activity [HofmannWellenhof et al., 2008]. In the first stage, there were two GNSS: the American Global Positioning System (GPS) and the Russian GLObal Navigation Satellite System (GLONASS). At present, the deployment of Beidou/Compass GNSS in China is nearly completed, more than half of the European Galileo system has been put into operation, SBAS (Satellite Based Augmentation System) satellites are being deployed.

On the one hand, GNSS have enabled a fairly autonomous accurate navigation, which is widely used in construction, agriculture, aviation, cartography, and other fields. On the other hand, GNSS provide extensive experimental material on ionospheric, atmospheric physics, and geodynamics. A large number of ionospheric studies have been carried out using GNSS dual-frequency phase measurements. The first works were done mostly with GPS due to the presence of a sufficient number of ground stations and stably operating constellation. In recent years, the Russian system GLONASS and alternative GNSS such as Beidou/Compass [Kunitsyn et al., 2016] and SBAS [Kunitsyn et al., 2015] have come into common use. In ionospheric research, the main parameter, determined through GNSS measurements, is the total electron content (TEC). The unit of measurement of TEC is TECU (Total Electron Content Unit), 1 TECU $=10^{16} \mathrm{~m}^{-2}$.

Most published works on GNSS ionospheric research deal with ionospheric irregularities of different scales [Afraimovich, Perevalova, 2006; Jakowski et al., 2012a; Afraimovich et al., 2013; Otsuka et al., 2013;
Ding et al., 2014] and ionospheric scintillations [Aarons, 1997; Mitchell et al., 2005], with ionospheric mapping [Hernández-Pajares et al., 2009], and GNSS radio tomography of the ionosphere [Ruffini et al., 1998; Mitchell, Spencer, 2003; Nesterov, Kunitsyn, 2011], as well as determine absolute ionospheric parameters [Yasyukevich et al., 2017a; Lanyi, Roth, 1988]. The data assimilation technique finds expanding applications. Data assimilative models such as Utah State University Global Assimilation of Ionospheric Measurements (USU-GAIM) Model [Schunk et al., 2004] or the model of the Central Aerological Observatory of Roshydromet [Solomentsev et al., 2012] are used both to study physics of processes and to address a number of other problems. In practice, GNSS are used to adjust radio systems [Afraimovich, Yasukevich, 2008; Yasukevich et al., 2017b], including radar systems [Ovodenko et al., 2015], and to improve models [Arikan et al., 2016], which is especially important in real-time systems [Zolesi et al., 2004].

Construction of indices of ionospheric conditions and near-Earth space based on GNSS data is being developed. At present, the ROTI index - Rate-of-TEC index [Pi et al., 1997] and its improved versions AATR - Along Arc TEC Rate [Juan et al., 2018], and DIX - Disturbance Ionosphere indeX [Jakowski et al ., 2012b] are widely known. There are indices describing ionospheric disturbances locally [Voeykov et al., 2016], regionally [Nesterov et al., 2017], and globally [Gulyaeva, Stanislawska, 2008]. In addition, a technique has been developed which estimates the general level of ionospheric plasma (global electron content (GEC)) [Afraimovich et al., 2008] from Global Ionosphere Maps (GIM) [Mannucci et al., 1998; Schaer et al., 1998].

For neutral-atmosphere physics, GNSS allow us to determine the water vapor content [Lukhneva et al., 
2016; Bevis et al., 1992] and to perform its tomographic reconstruction [Bender et al., 2011; Dong, Jin, 2018]. In recent years, studies on the monitoring of rains based on such data have been carried out [Priego et al., 2017].

For geodynamics, GNSS measurements make it possible to determine coseismic and postseismic deformations, lithospheric plate motion, and earth's crustal deformation at the boundary of these plates, caused by volcanic activity and static ice pressure [Sankov et al., 2014; Segall, Davis, 1997; Mazzotti et al., 2003; Lukhnev et al., 2010; Shestakov et al., 2011]. A number of interesting studies deal with seismoionospheric coupling [Devi et al., 2014; Jin et al., 2015] and explosive impact of space bodies [Perevalova et al., 2015]. We should also mention works on the use of GNSS for reflectometry observations such as measurements of sea level [Larson, Nievinski, 2013; Padokhin et al., 2017] and snow depth [Löfgren et al., 2011].

All these studies were promoted by the development of global and regional GNSS networks with free access to their data. One of the major networks, providing data for the global community, is the International GNSS Service (IGS) - an international union that uses equipment of various institutions [Dow et al., 2009]. There are other fairly large networks such as UNAVCO [http://www.unavco.org ]. One of the largest regional GSI (Geospatial Information Authority) networks in Japan comprises $\sim 1200$ stations [ftp://terras.gsi.go.jp/data]. In addition, there are fairly small networks in areas of higher interest such as Canadian High Arctic Ionospheric Network CHAIN [Jayachandran et al., 2009], Korea Astronomy and Space Science Institute Global Data Center (KASI GDC) [ftp://nfs.kasi.re.kr/gps/data/daily], Système d'Observation du Niveau des Eaux Littorales (SONEL) [ftp://ftp.sonel.org/gps/data], TrigNet [ftp://ftp.trignet.co.za], etc. Today, the total number of receivers is $\sim 8000$ [Tsugawa et al., 2018].

In the Russian Federation, there are a number of continuously operating GNSS networks such as: HIVE (Industrial geodetic systems, [https://hive.geosystems.aero]), SmartNet [http://smartnet-ru.com], EFT-CORS [https:// eft-cors.ru], RTKNet «Geodetica» [http://rtknet.ru], as well as Roshydromet network [Alpatov et al., 2012] and FEB RAS network [Sorokin et al., 2017]. It is worth noting that most of these networks are located in European Russia, and their data are not always readily available. Accordingly, it is important to establish a GNSS network in Siberia. This paper describes the current state of the Siberian GNSS Network SibNet of continuously operating GNSS receivers, its technical characteristics and performance potential.

\section{SIBNET COMPOSITION AND TECHNICAL CHARACTERISTICS OF RECEIVERS}

The Institute of Solar-Terrestrial Physics of Siberian Branch of Russian Academy of Sciences (ISTP SB RAS) began to deploy SibNet in 2011. The main purpose of this network is to monitor the ionosphere and ionospher- ic disturbances. At the same time, it provides the possibility of using SibNet data for geodynamic research. In the first stage of the network deployment (2011-2015), JAVAD receivers were bought and installed. In the second phase (2015-2018), in addition to the JAVAD receivers, NovAtel receivers were installed.

The continuous operation of the network requires an infrastructure involving steady electric power supply, temperature and humidity control, security, data transfer channel (if possible) at the receiver location. The receivers were therefore placed at the ISTP SB RAS observatories that are located in the Irkutsk Region, Republic of Buryatia, Krasnoyarsk Territory. The locations of SibNet receivers are shown in Figure 1. You can see that all the stations except one are located around Lake Baikal and quite closely grouped in latitude.

Table lists parameters of SibNet receivers. Here, $\varphi$, $P, \Delta f, I / Q, \sigma \varphi, S 4$ denote the carrier phase, pseudorange, Doppler shift, in-phase/quadrature signal components, standard deviation of the carrier phase, and amplitude scintillation index respectively. Most JAVAD receivers detect GPS, GLONASS, Galileo, and SBAS signals. One of the receivers (in the village of Listvianka, LIST) records signals from the Chinese Navigation Satellite System Compass/Beidou.

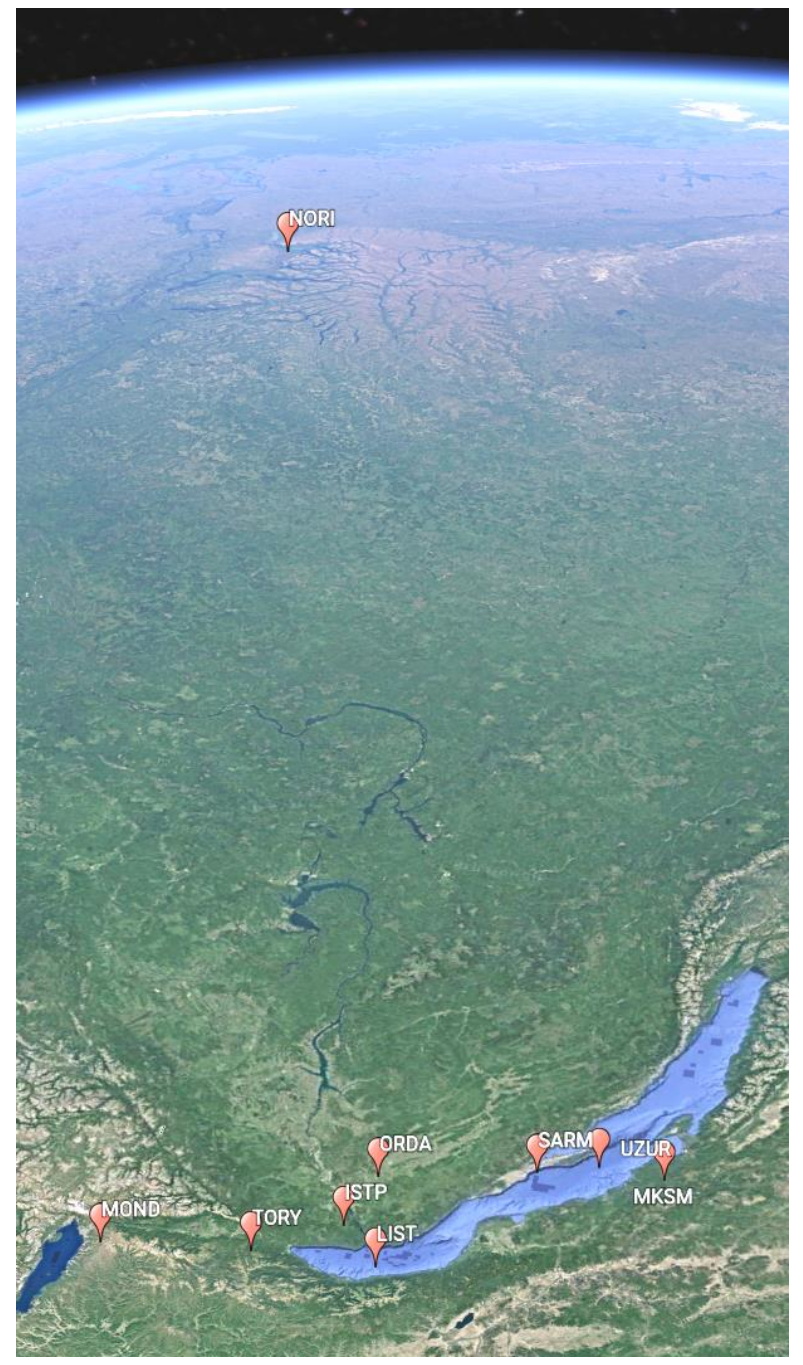

Figure 1. Locations of SibNet receivers 
Receiving equipment parameters

\begin{tabular}{|c|c|c|c|c|c|c|c|}
\hline Station & Receiver/Antenna & $\begin{array}{l}\text { Recorded } \\
\text { signals }\end{array}$ & $\begin{array}{l}\text { Recorded } \\
\text { parameters }\end{array}$ & $\begin{array}{c}\text { Temporal } \\
\text { resolution } \\
\text { (regular/ } \\
\text { maximum), s } \\
\end{array}$ & $\begin{array}{c}\text { Date of the } \\
\text { beginning of } \\
\text { test meas- } \\
\text { urements } \\
\end{array}$ & $\begin{array}{l}\text { Data } \\
\text { channel }\end{array}$ & Location \\
\hline \multirow{2}{*}{ ISTP } & $\begin{array}{l}\text { JAVAD Delta-G3T / } \\
\text { Javad RingAnt-G3T }\end{array}$ & $\begin{array}{l}\text { GPS L1/L2/L5; } \\
\text { GLONASS L1/L2; } \\
\text { Galileo E1/E5A; } \\
\text { SBAS L1/L5 }\end{array}$ & $\varphi, P, \Delta f, I / Q$ & $0.02 / 0.02$ & $\begin{array}{l}\text { February 16, } \\
2012\end{array}$ & \multirow{2}{*}{+} & \multirow{2}{*}{$\begin{array}{l}\text { Irkutsk, } \\
\text { Irkutsk Region, } \\
52.2^{\circ} \mathrm{N}, 104.3^{\circ} \mathrm{E}\end{array}$} \\
\hline & $\begin{array}{l}\text { NovAtel GPStation-6/ } \\
\text { Javad RingAnt-G3T }\end{array}$ & $\begin{array}{l}\text { GPS L1/L2/L5; } \\
\text { GLONASS L1/L2 }\end{array}$ & $\begin{array}{c}\varphi, P, \Delta f, \\
S 4, \sigma \varphi\end{array}$ & $\begin{array}{l}1 / 0.02 \\
60 / 60\end{array}$ & $\begin{array}{l}\text { August 07, } \\
2014\end{array}$ & & \\
\hline \multirow[t]{2}{*}{ TORY } & $\begin{array}{l}\text { JAVAD SigmaQ-G3T } \\
\text { (with the possibility of } \\
\text { receiving a signal } \\
\text { from } 4 \text { antennas)/3 } \\
\text { Javad RingAnt-G3T } \\
\text { antennas } \\
\end{array}$ & $\begin{array}{l}\text { Antenna 1: GPS L1/L2; } \\
\text { GLONASS L1/L2; } \\
\text { Galileo E1/E5A; SBAS } \\
\text { L1/L5 } \\
\text { Antenna 2: GPS L1/L2 }\end{array}$ & $\varphi, P, \Delta f, I / Q$ & $1 / 0.02$ & $\begin{array}{l}\text { March 20, } \\
2012\end{array}$ & \multirow[t]{2}{*}{+} & \multirow{2}{*}{$\begin{array}{l}\text { the village of Tory, } \\
\text { Republic } \\
\text { of Buryatia, } \\
51.8^{\circ} \mathrm{N}, 103.1^{\circ} \mathrm{E}\end{array}$} \\
\hline & $\begin{array}{l}\text { NovAtel GPStation-6 / } \\
\text { Javad RingAnt-G3T }\end{array}$ & $\begin{array}{l}\text { GPS L1/L2/L5; } \\
\text { GLONASS L1/L2 }\end{array}$ & $\begin{array}{c}\varphi, P, \Delta f \\
S 4, \sigma \varphi\end{array}$ & $\begin{array}{l}1 / 0.02 \\
60 / 60\end{array}$ & $\begin{array}{l}\text { July } 16 \\
2016\end{array}$ & & \\
\hline \multirow{2}{*}{ NORI } & $\begin{array}{l}\text { JAVAD Delta-G3T / } \\
\text { Javad RingAnt-G3T }\end{array}$ & $\begin{array}{l}\text { GPS L1/L2/L5; } \\
\text { GLONASS L1/L2; } \\
\text { Galileo E1/E5A; SBAS } \\
\text { L1/L5 }\end{array}$ & $\varphi, P, \Delta f, I / Q$ & $1 / 1$ & $\begin{array}{l}\text { October 11, } \\
2014\end{array}$ & \multirow{2}{*}{+} & \multirow{2}{*}{$\begin{array}{l}\text { Norilsk, } \\
\text { Krasnoyarsk Territo- } \\
\text { ry, } \\
70.0^{\circ} \mathrm{N}, 88.0^{\circ} \mathrm{E}\end{array}$} \\
\hline & $\begin{array}{l}\text { NovAtel GPStation-6 / } \\
\text { Javad RingAnt-G3T }\end{array}$ & $\begin{array}{l}\text { GPS L1/L2/L5; } \\
\text { GLONASS L1/L2 }\end{array}$ & $\begin{array}{c}\varphi, P, \Delta f, \\
S 4, \sigma \varphi\end{array}$ & $\begin{array}{l}1 / 0.02 \\
60 / 60\end{array}$ & $\begin{array}{l}\text { February 14, } \\
2018\end{array}$ & & \\
\hline LIST & \multirow{6}{*}{ JAVAD Delta-G3T } & $\begin{array}{l}\text { GPS L1/L2/L5; } \\
\text { GLONASS L1/L2 } \\
\text { Beidou L2/L7 }\end{array}$ & \multirow{6}{*}{$\varphi, P, \Delta f, I / Q$} & $1 / 0.02$ & $\begin{array}{l}\text { June } 15, \\
2012\end{array}$ & + & $\begin{array}{l}\text { the village of } \\
\text { Listvyanka, Irkutsk } \\
\text { Region, } \\
51.8^{\circ} \mathrm{N}, 104.9^{\circ} \mathrm{E}\end{array}$ \\
\hline MOND & & \multirow{5}{*}{$\begin{array}{l}\text { GPS L1/L2/L5; } \\
\text { GLONASS L1/L2; } \\
\text { Galileo E1/E5A; SBAS } \\
\text { L1/L5 }\end{array}$} & & $1 / 0.02$ & $\begin{array}{l}\text { September } \\
11,2012\end{array}$ & + & $\begin{array}{l}\text { the village of Mon- } \\
\text { dy } \\
\text { Republic } \\
\text { of Buryatia, } \\
51.6^{\circ} \mathrm{N}, 100.9^{\circ} \mathrm{E}\end{array}$ \\
\hline ORDA & & & & $1 / 0.02$ & $\begin{array}{l}\text { June 14, } \\
2011\end{array}$ & - & $\begin{array}{l}\text { Mishelevka, Irkutsk } \\
\text { Region, } \\
52.9^{\circ} \mathrm{N}, 103.3^{\circ} \mathrm{E}\end{array}$ \\
\hline SARM & & & & $1 / 0.02$ & $\begin{array}{l}\text { December } \\
02,2013\end{array}$ & + & $\begin{array}{l}\text { the village of Sar- } \\
\text { ma, } \\
\text { Irkutsk Region, } \\
53.1^{\circ} \mathrm{N}, 106.8^{\circ} \mathrm{E} \\
\end{array}$ \\
\hline UZUR & & & & $1 / 0.02$ & $\begin{array}{l}\text { March 18, } \\
2013\end{array}$ & + & $\begin{array}{l}\text { the village of Uzur, } \\
\text { Irkutsk Region, } \\
53.3^{\circ} \mathrm{N}, 107.7^{\circ} \mathrm{E}\end{array}$ \\
\hline $\begin{array}{l}\text { MKSM } \\
\text { Auxiliary } \\
\text { station }\end{array}$ & & & & $1 / 1$ & $\begin{array}{l}\text { April 27, } \\
2014\end{array}$ & - & $\begin{array}{l}\text { the village of } \\
\text { Maksimikha, } \\
\text { Republic } \\
\text { of Buryatia } \\
53.3^{\circ} \mathrm{N}, 108.7^{\circ} \mathrm{E} \\
\end{array}$ \\
\hline
\end{tabular}

The detection of SBAS and Beidou signals allows geostationary measurements by almost motionless lines of sight (LOS) [Kunitsyn et al., 2015, 2016]. The JAVAD receivers is presented in Figure 2, $a, b$. the JAVAD Delta-G3T receivers (Figure 2, a) placed in ISTP, NORI, LIST, MOND, ORDA, SARM, UZUR, MKSM, and the JAVAD SimgaQ-G3T receiver (Figure $2, b)$ in TORY are equipped with RingAnt-G3T antennas (Figure 2,e) with multipath reduction. The light weight antenna GrAnt-G3T (Figure 2,d) is utilized for field measurements.

Most SibNet JAVAD receivers can make measurements with $50 \mathrm{~Hz}$ cadence. For the main problems of ionospheric physics and near-Earth space monitoring, such resolution is unreasonably high. The daily data volume at one station in the recording mode of $50 \mathrm{~Hz}$ is about $10 \mathrm{~GB}$, which considerably complicates data transfer and storage and makes it inappropriate to record such data across the network in a regular measurement mode. Hence, only one of the receivers makes a permanent recording at $50 \mathrm{~Hz}$. To reduce costs for data transfer, the ISTP station located in the ISTP SB RAS building has been selected as such a receiver. 

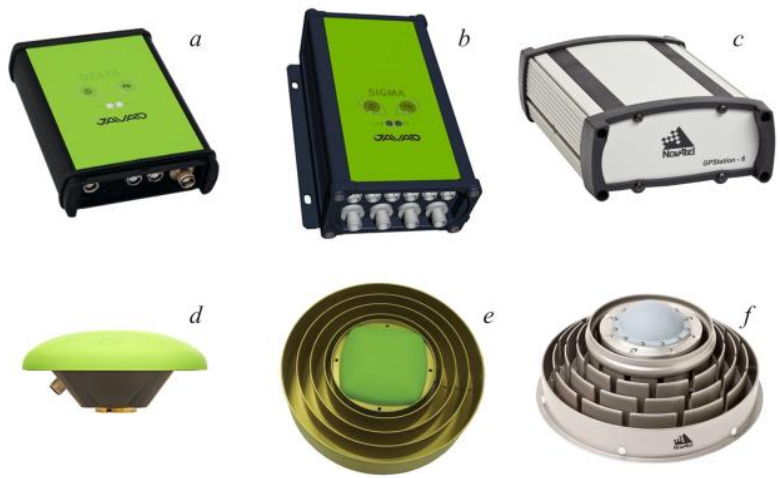

Figure 2. Equipment used in SibNet. Upper row: GNSS receivers JAVAD Delta $(a)$, JAVAD SigmaQ $(b)$, NovAtel GPStation-6 (c). Bottom row: GNSS antennas GrAnt-G3T $(d)$, RingAnt-G3T (e), GNSS-750 ( $f$ )

NovAtel GPStation-6 receivers are specialized equipment for measuring amplitude and phase scintillations [Shanmugam et al., 2012]. Such measurements enable us to analyze the small-scale structure of ionospheric disturbances [Yeh, Liu, 1982].

The NovAtel GPStation-6 receiver measures the amplitude scintillation index $S 4$ and the standard deviation of the carrier phase $\sigma \varphi$ at GPS L1/L2/L5 and GLONASS L1/L2 frequencies. Temporal resolution of these measurements is $1 \mathrm{~min}$. The NovAtel receiver with GNSS-750 antenna is shown in Figure 2, $c, f$. These receivers are currently installed in ISTP, TORY, and NORI.

At present, ISTP, TORY, NORI, LIST, MOND, UZUR, and SARM have data transfer channels. Measurement data from these stations can be quite readily transferred to ISTP SB RAS and processed. Data from other stations are sent by courier at intervals of one month to six months. At MKSM, equipment is operating in a test mode.

\section{FEATURES OF MEASUREMENTS AT THE GEOPHYSICAL OBSERVATORY (TORY)}

The ISTP SB RAS Geophysical Observatory (Tory) is currently equipped with two receivers - JAVAD SigmaQ-G3T and NovAtel GPStation-6. The JAVAD SigmaQ-G3T receiver can record GPS satellite signals with four spaced antennas simultaneously and GLONASS signals with the main antenna. This enabled us to deploy an $\sim 20 \mathrm{~m}$ small-base interferometer for making measurements with three antennas (TORY-A the main antenna, TORY-B, TORY-C; see Figure 3). It can be used to determine velocities and directions of small-scale irregularities by methods analogous to those developed in [Afraimovich, 1982; Afraimovich, Perevalova, 2006]. To complement these small-base measurements, a NovAtel GPStation-6 receiver analogous to that placed in ISTP was installed in 2016.

The complex to detect small-scale irregularities is placed in Tory due to the presence of additional optical and radio physical facilities there [Afraimovich et al., 2012] as well as due to the state-of-the-art observation equipment that is planned to be installed in the near future under the project "RAS National Heliogeophysical Complex" [Olemskoy, 2017].

\section{DATA BANK}

SibNet GNSS measurements are stored on the server in ISTP SB RAS. Figure 4 presents the statistics of data coverage with $50 \mathrm{~Hz}$ cadence at the ISTP site (ISTP SB RAS building in Irkutsk), whose data have the highest coverage. Each bar in Figure 4 corresponds to an observation month. The beginning of the diagram is January 2012.

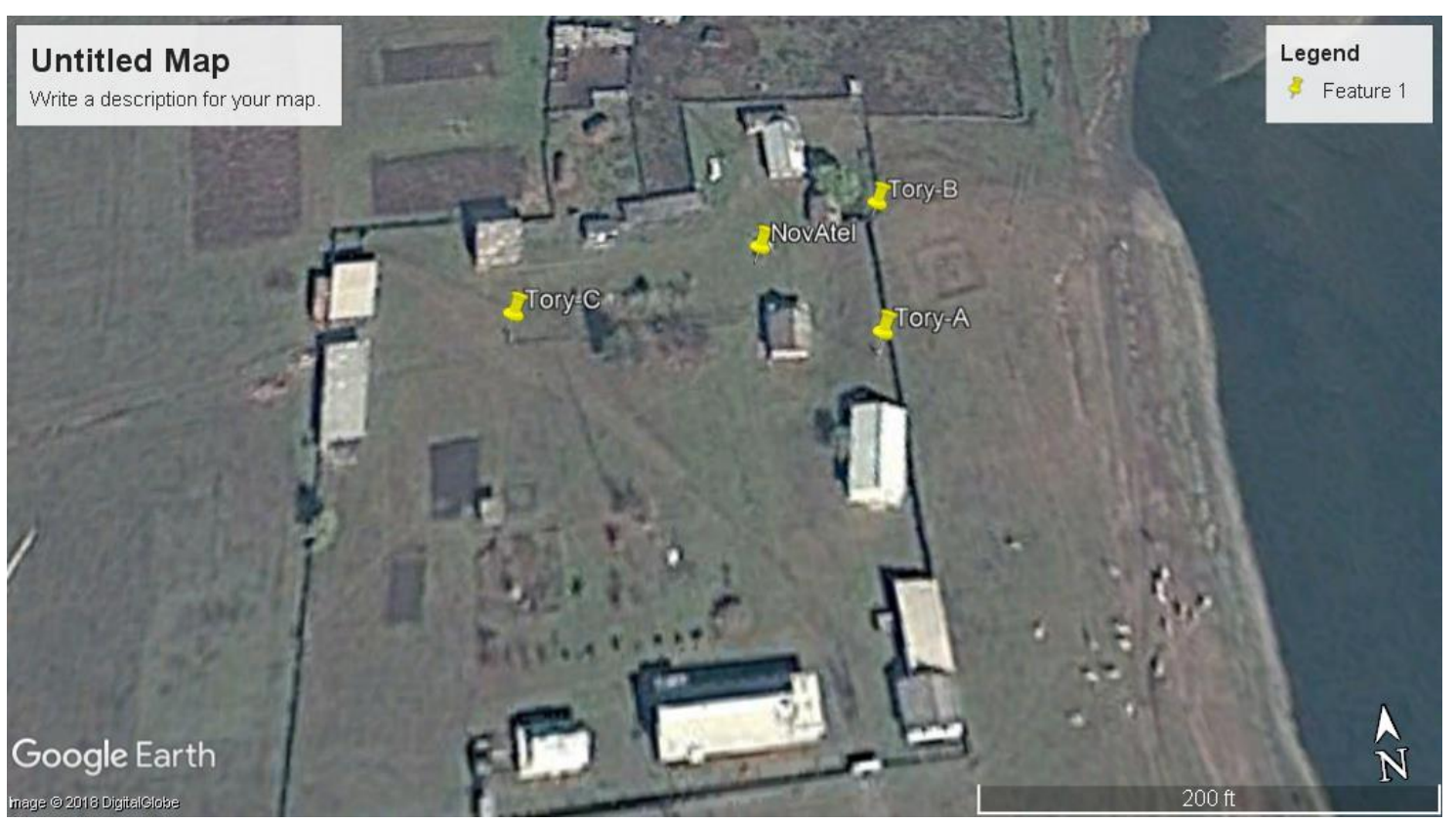

Figure 3. Location of receiving facilities in the Geophysical Observatory (Tory). Marks indicate locations of NovAtel receiver's antenna and three antennas of the JAVAD SigmaQ-G3T receiver (Tory-A, Tory-B, Tory-C) 
ISTP 2012-2018

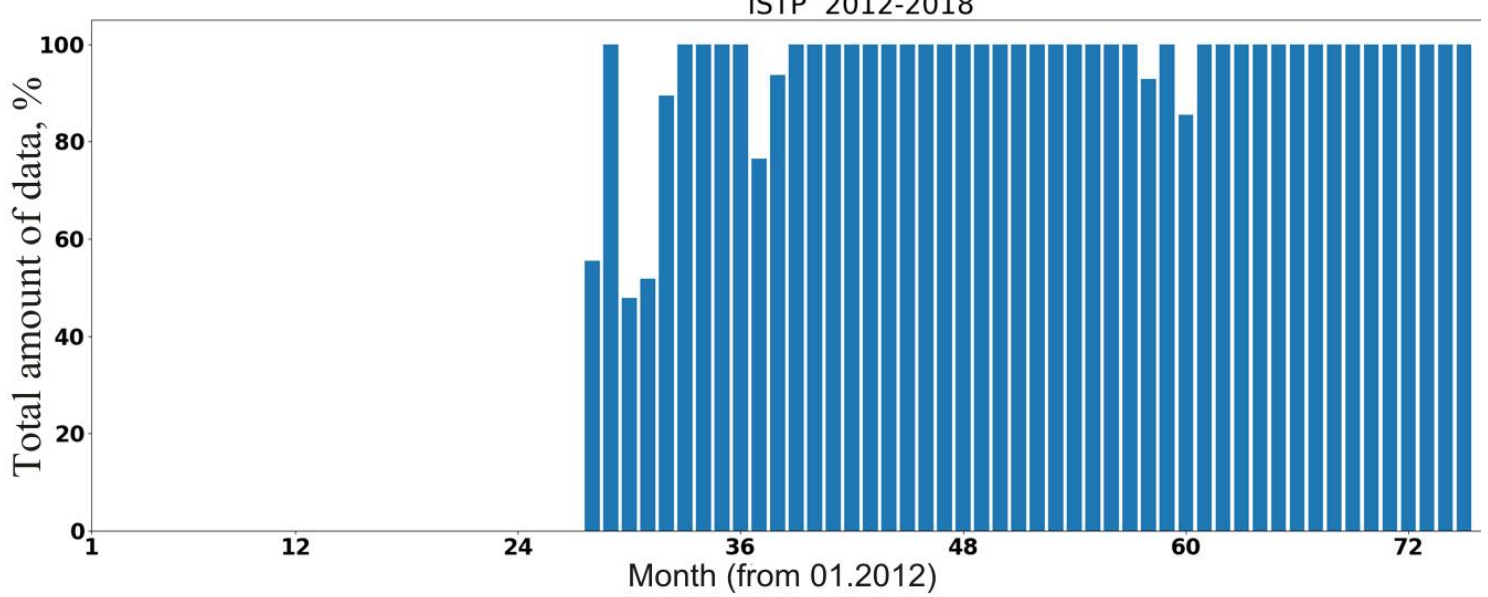

Figure 4. Amount of recorded data with $50 \mathrm{~Hz}$ cadence at ISTP. The Figure shows the total amount of data as a percentage of the theoretical monthly one

Figure 5 presents the statistics of data coverage with $1 \mathrm{~Hz}$ cadence at SibNet sites (LIST, MKSM, MOND, NORI, ORDA, SARM, UZUR, TORY). The lack of data for 2017-2018 at ORDA, SARM, MKSM is due to the absence of data transfer channel. As can be seen, there occur fairly frequent failures in the operation of the receivers, which are caused by various reasons. Gaps in NORI measurements are associated with poor quality of power supply and with emergency shutdowns of the equipment. The problem with the power supply in LIST leads to constant UPS battery failures and hence to a decrease in the reliability of control computer. In LIST and UZUR there were breaks in antenna cable. In TORY in 2016-2017 there was a software failure. The remoteness of the observation stations causes additional difficulties in restoring the equipment operation.
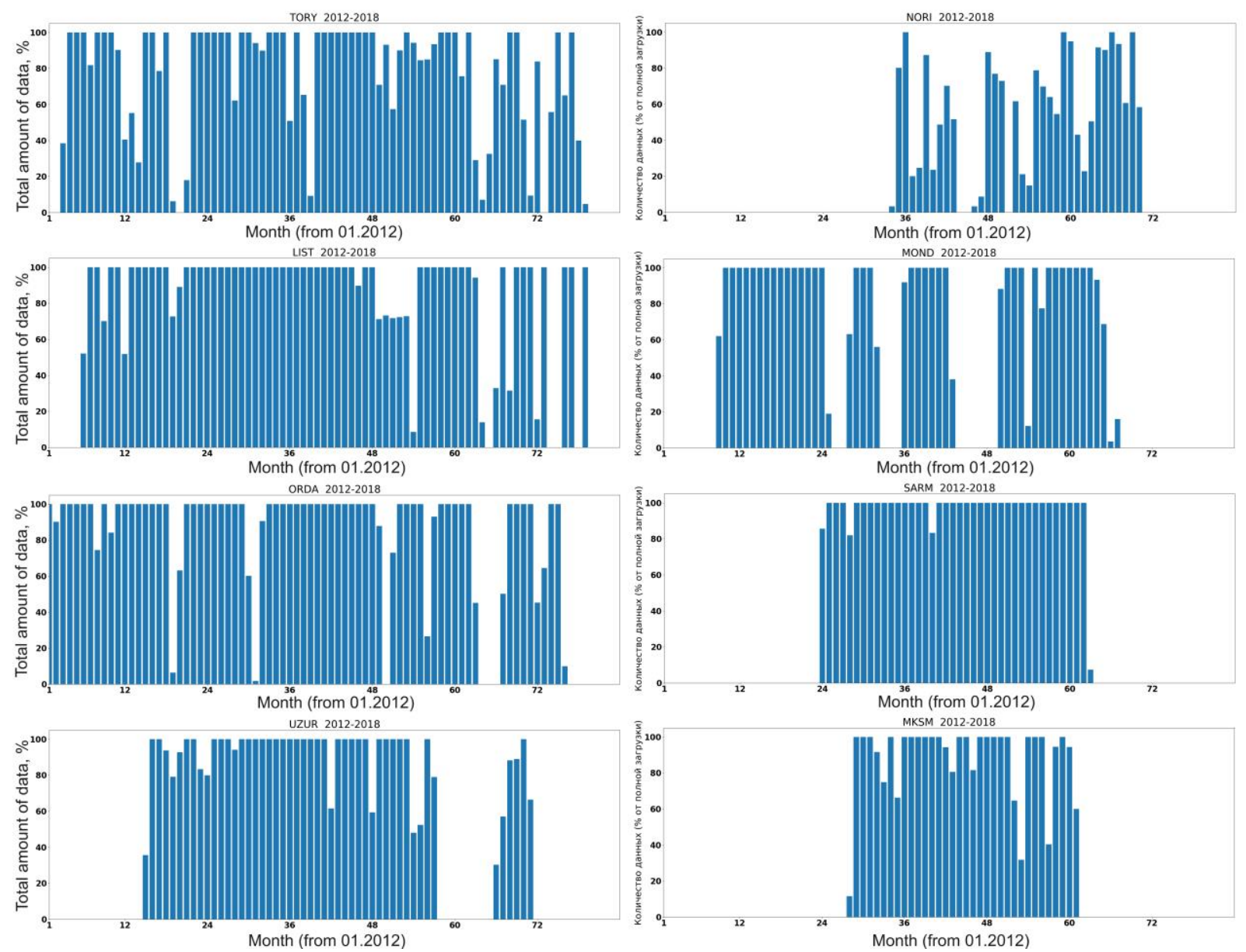

Figure 5. Amount of recorded data with $1 \mathrm{~Hz}$ cadence at SibNet receivers. Names of stations are given on panels. The Figure shows the total amount of data as a percentage of the theoretical monthly one 


\section{EXAMPLES OF EXPERIMENTAL OBSERVATIONS}

This section gives examples of the use of SibNet measurements. As an example, we have chosen the June 22-23, 2015 magnetic storm [Astafyeva et al., 2017].

\subsection{TEC variations}

One of the main ionospheric parameters determined by GNSS is the total electron content (TEC) and its variations. Figure 6 shows the dynamics of geostationary TEC along the ORDA-SBAS S27 LOS $(a)$, as well as GNSS-TEC along the NORI-GPS G01 LOS $(b)$. Geostationary data provide diurnal TEC variation. During the main phase of the June 22-23, 2015 storm, the diurnal variation exhibits a pronounced increase in the intensity of TEC variations at $0-5$ UT on June 23 (Figure 6, $a$ ).

NORI data (Figure $6, b$ ) made it possible to detect an intense localized TEC disturbance with an amplitude of $\sim 5$ TECU on June 22, 2015, as well as a long-lived quasiperiodic structure with an amplitude of $\sim 1$ TECU and a period of $\sim 30$ min on June 23, 2015

\subsection{Ionospheric disturbance}

As mentioned above, methods of estimating ionospheric disturbances have been developed quite extensively in recent years. Voeykov et al. [2016] have proposed an ionospheric disturbance index representing the mean intensity of TEC variations in a given spectral window at a single station. Figure 7 shows the dynamics of the disturbance index WTEC (blue curve) for variations with periods up to $10 \mathrm{~min}$ as derived from ORDA data. We can see that after the onset of the magnetic storm at $\sim 18: 30$ UT on June 22, 2015 there is a significant increase in the ionospheric disturbance index $\sim 8-9$ times compared to the background level. Maximum WTEC coincides in time with minimum SYM-H (black curve), recorded on June 22, 2015.
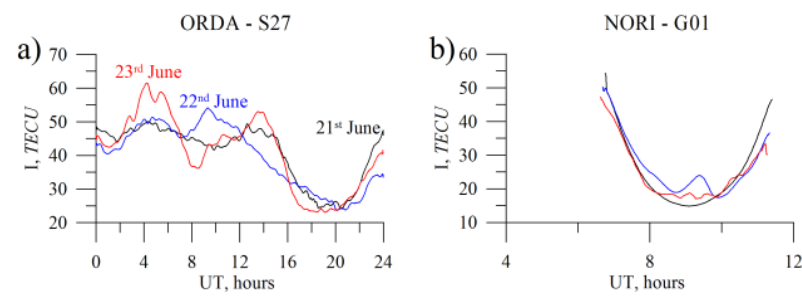

Figure 6. Dynamics of TEC along ORDA - S27 $(a)$ and NORI - G01 LOS $(b)$ on June 21-23, 2015. On panel $a$, dashed lines are 18:30 UT on June 22 and 06:00 UT on June 23; the gray curve indicates $S Y M-H$ variations (right scale). On panel $b$, the black line shows measurements made on June 21; the blue line, on June 22; the red line, on June 23

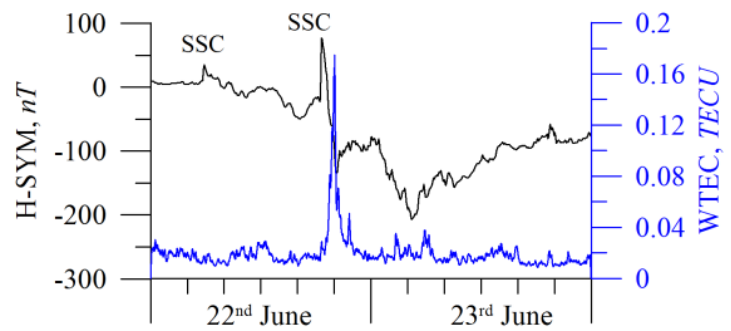

Figure 7. Dynamics of WTEC (blue curve) and SYM-H (black curve) during the June 22-23, 2015 magnetic storm
Then, WTEC gradually returns to the undisturbed level. After the beginning of the second storm intensification, which is characterized by a $S Y M-H$ decrease on July 23, 2015 and a global minimum, such a high level of ionospheric disturbance is not observed, although in general there is a 1.5-2-fold increase in WTEC compared to the background level.

\subsection{Maps of TEC variations}

SibNet can provide information about the spatial structure of ionospheric disturbances through simultaneous observations at different GNSS stations located in different regions. As a result, there is a considerable number of satellite-receiver LOS with different geometries, which simultaneously penetrate the ionosphere. For automatic processing of large amount of GNSS data and mapping TEC, ISTP SB RAS has developed the SIMuRG system - the System for the Ionosphere Monitoring and Researching from GNSS [https://simurg.iszf.irk.ru; Yasyukevich et al., 2018].

Figure 8 presents maps of $2-10 \mathrm{~min}$ TEC variations obtained with SIMuRG for June 22, 2015. The maps are based on GPS/GLONASS/Galileo/SBAS GNSS data. It can be seen (Figure 8) that after the storm onset at $\sim 18: 45$ UT in the high-latitude region there occurs a negative disturbance, which propagates to midlatitudes. By 20:00 UT (LT daylight hours), the disturbance reaches the latitudes of Lake Baikal and is detected there as intense negative TEC variations. The maps show that the negative disturbance does not propagate below $50^{\circ}$.

\subsection{Positioning}

For highly accurate positioning of an individual station, we have used the PPP software (Precise Point Position) [Zhou et al., 2018]. Figure 9 exemplifies the dynamics of the geomagnetic index SYM-H (solid gray curve) and the dynamic of deviations from a randomly chosen value of the coordinate $Y$ in the WGS84 system, which are determined in the dual-frequency PPP-GPS mode at NORI and ORDA. For the mid-latitude station ORDA, in spite of disturbed geomagnetic conditions, there are no sudden changes in the coordinate with time. For the high-latitude station NORI on June 22, 2015 during the first recorded minimum of $S Y M-H$, there is a sharp increase in the positioning error. Moreover, there is a sharp increase in the error for this station during the recovery phase on June 23, 2015. Thus, for high latitudes the precise point positioning can be characterized by an increase in errors during magnetic storms.

\section{WORK DIRECTIONS AND MEASUREMENT FEATURES}

SibNet can solve the following key problems:

1) to monitor medium and large-scale traveling ionospheric disturbances, determination of their velocity and direction;

2) small-base study of small-scale irregularities and their dynamics;

3) to study phase and amplitude scintillations at GNSS frequencies; 
4) to monitor and study ionospheric disturbances associated with magnetospheric activity;

5) to study mid-latitude auroral disturbances;

6) to study space weather effects on characteristics of radio facilitates;

7) GNSS data integrity and positioning accuracy control;

8) geodynamic studies in the Baikal Rift Zone.

Features of SibNet are

1) high temporal resolution (measurement frequency up to $50 \mathrm{~Hz}$ );
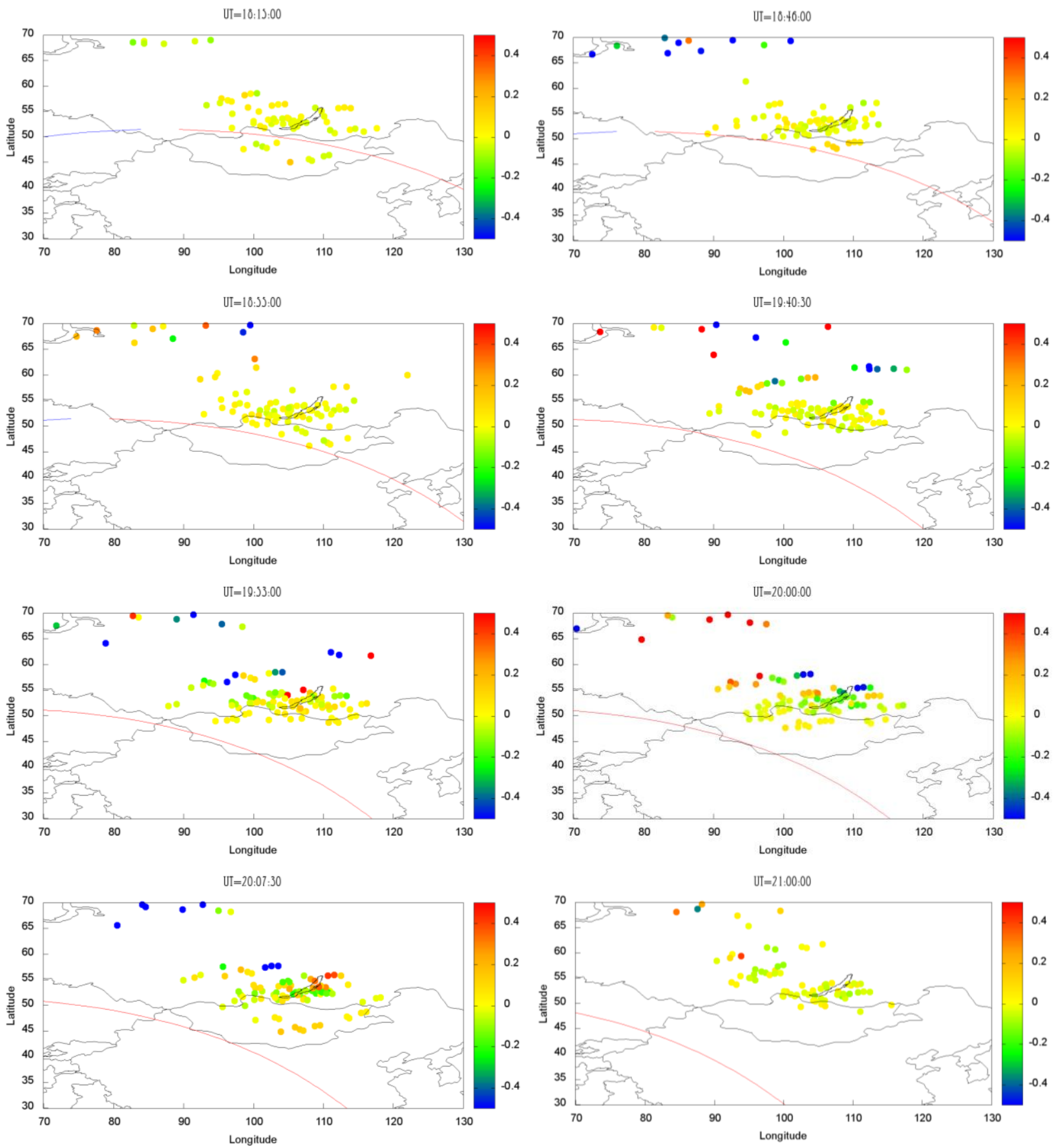

Figure 8. Maps of the spatial distribution of 2-10 min TEC variations for June 22, 2015. Red and blue lines mark sunrise and sunset solar terminators at a height of $300 \mathrm{~km}$
2) measurement of signals from independent systems including GPS, GLONASS, Galileo (Beidou with one of the receivers), as well as SBAS signals;

3) combined joint measurements of phase, pseudorange, quadrature components, as well as amplitude and phase scintillations at individual points;

4) extensive experimental facilities in the region, which significantly supplements the measurements [Afraimovich et al., 2012; Olemskoy, 2017]. 


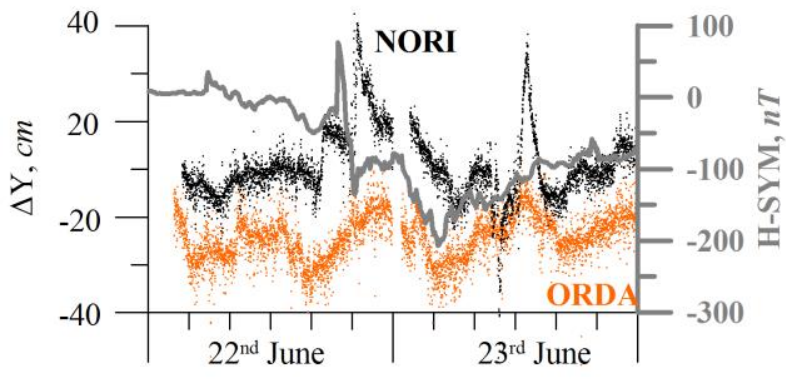

Figure 9. Dynamics of $Y$ deviations at NORI (black dots) and ORDA (orange dots) on June 22-23, 2015. For comparison, the gray curve shows the dynamics of the magnetic disturbance index $S Y M-H$ (right scale)

\section{CONCLUSION}

The network of dual-frequency GNSS receivers SibNet presented in this paper can be used for a wide range of research and applied problems. The network was created at ISTP SB RAS. It is located in the Siberian region. At present there are eight continuously operating stations and one auxiliary station in SibNet. These stations are equipped with JAVAD GNSS receivers enabling us to monitor ionospheric conditions. In addition, there are three NovAtel GPStation-6 receivers providing data on ionospheric scintillations.

SibNet is included in Center for Common Use "Angara" [http://ckp-rf.ru/ckp/3056] and can be used by external users. A key problem is currently to achieve consistency of unattended operation of the entire network. A new stage of the work on the development of the network of receivers is to develop the SIMuRG system for automatic GNSS data processing [https://simurg.iszf.irk.ru].

We are deeply grateful to prof. E.L. Afraimovich (March 12, 1940-October 08, 2009) for initiation of works on the development of SibNet, as well as to academician G.A. Zherebtsov, corr.-member of RAS A.P. Potekhin, D.Sc. (Phys.\&Math.) V.I. Kurkin, D.Sc. (Phys.\&Math.) A.V. Medvedev for advancement and support of the project. We thank A.B. Ishin, S.V. Voeykov, I.K. Edemsky, P.V. Tatarinov, V.V. Demyanov, E.A. Kosogorov for participation in works on organization and deployment of SibNet, A.A. Perevalov for software, prof. V.E. Kunitsyn (June 24, 1955-July 07, 2015) and A.M. Padokhin for consultative assistance, V.F. Belkin (February 21, 1939-October 29, 2016), V.M. Aleshkov, D.S. Kushnarev, A.A. Lukovnikova for the assistance in installing GNSS receivers in test sites, V.A. Sankov for the teamwork at initial stages of the network deployment. We are grateful to JAVAD GNSS, and in particular to Yu. Nuzhnova, S. Organov, V. Yakovlev for their assistance in organizing the operation of equipment.

We are grateful to OMNIWeb Plus service [ http://omniweb.gsfc.nasa.gov] for geophysical data. The work was performed with budgetary funding of Basic Research program II.16, using the equipment of Center for Common Use "Angara" http://ckp-rf.ru/ckp/3056. Processing of TEC variation series was funded by Russian Science Foundation grant No. 17-77-20005.

\section{REFERENCES}

Aarons J. Global positioning system phase fluctuations at auroral latitudes. J. Geophys. Res. 1997, vol. 102, A8, pp. 17219-17231. DOI: 10.1029/97JA01118.

Afraimovich E.L. Interferentsionnye metody zondirovaniya ionosfery [Interferometry techniques for ionospheric radiosensing]. Moscow, Nauka Publ., 1982. 198 p. (In Russian).

Afraimovich E.L., Perevalova N.P. GPS monitoring verkhei atmosfery Zemli [GPS monitoring of the Earth's upper atmosphere]. Irkutsk, SC RRS SB RAMS Publ., 2006, 480 p. (In Russian).

Afraimovich E.L., Yasukevich Yu.V. Using GPSGLONASS-GALILEO data and IRI modeling for ionospheric calibration of radio telescopes and radio interferometers. $J$. Atmos. Solar-Terr. Phys. 2008, vol. 70, no. 15, pp. 19491962. DOI: $10.1016 / j$ j.jastp.2008.05.006.

Afraimovich E.L., Astafyeva E.I., Oinats A.V., Yasukevich Yu.V., Zhivetiev I.V. Global electron content: a new conception to track solar activity. Ann. Geophys. 2008, vol. 26, pp. 335-344. DOI: 10.5194/angeo-26-335-2008.

Afraimovich E.L., Zherebtsov G.A., Perevalova N.P., Sankov V.A., Bashkuyev Yu.B., Kurkin V.I., Kovalenko V.A., Rakhmatulin R.A., Mikhalev A.V., Berngardt O.I., Aleshkov V.M., Lipko Yu.V., Pirog O.M., Polekh N.M., Voeykov S.V., Yasyukevich Yu.V., Ishin A.B., Edemskiy I.K., Podlesny A.V., Brynko I.G., Pashinin A.Yu., Molodykh S.I., Ivanova V.A., Astafyeva E.I., Polyakova A.S., Lukhnev A.V., Lukhneva O.F., Ashurkov S.V., Dobrynina A.A., Byzov L.M., Miroshnichenko A.I., Chernykh E.N., Dembelov M.G., Buyanova D.G., Naguslaeva I.B., Khaptanov V.B., Angarkhaeva L.Kh., Advokatov V.R., Balkhanov V.K., Ayurov D.B., Khomutov S.Yu., Zhivetiev I.V. Seismo-ionosphernye $i$ seismoelectromagnitnye protsessy $v$ Baykalskoi riftovoi zone [Seismoionospheric and Seismoelectromagnetic Processes in the Baikal Rift Zone]. Ed. G.A. Zherebtsov. Novosibirsk, SO RAN Publ., 2012. (In Russian).

Afraimovich E.L., Astafyeva E.I., Dem'yanov V.V., Edemskiy I.K., Gavrilyuk N.S., Ishin A.B., Kosogorov E.A., Leonovich L.A., Lesyuta O.S., Palamartchouk K.S., Perevalova N.P., Polyakova A.S., Smolkov G.Y., Voeykov S.V., Yasyukevich Yu.V., Zhivetiev I.V. Review of GPS/GLONASS studies of the ionospheric response to natural and anthropogenic processes and phenomena. J. Space Weather and Space Climate. 2013, vol. 3, A27. DOI: 10.1051/swsc/2013049.

Alpatov V.V., Kunitsyn V.E., Lapshin V.B., Romanov A.A., Tasenko S.V. Experience of creation by Roshydromet of radiotomography network for the ionosphere research and monitoring. Geliogeofizicheskie issledovaniya [Heliogeophys. Res.]. 2012, iss. 2. pp. 60-71. (In Russian).

Arikan F., Shukurov S., Tuna H., Arikan O., Gulyaeva T.L. Performance of GPS slant total electron content and IRI-PlasSTEC for days with ionospheric disturbance. Geodesy and Geodynamics. 2016, vol. 7, no. 1, pp. 1-10. DOI: 10.1016/j.geog. 2015.12.009.

Astafyeva E., Zakharenkova I., Huba J.D., Doornbos E., van den IJssel J. Global Ionospheric and thermospheric effects of the June 2015 geomagnetic disturbances: Multi-instrumental observations and modeling. J. Geophys. Res.: Space Phys. 2017, vol. 122, pp. 11,716-11,742. DOI: 10.1002/2017JA024174.

Bender M., Dick G., Ge M., Deng Z., Wickert J., Kahle H.-G., Raabe A., Tetzlaf G. Development of a GNSS water vapour tomography system using algebraic reconstruction techniques. Adv. Space Res. 2011, vol. 47, pp. 1704-1720. DOI: 10.1016/ j.asr.2010.05.034.

Bevis M., Businger S., Herring T.A., Rocken C., Anthes R.A., Ware R.H. GPS meteorology: Remote sensing of atmospheric wa- 
ter vapor using the global positioning system. J. Geophys. Res. 1992, vol. 97, D14, pp. 15787-15801. DOI: 10.1029/92JD01517.

Devi M., Barbara A.K., Oyama K.-I., Chen C.-H. Earthquake induced dynamics at the ionosphere in presence of magnetic storm. Adv. Space Res. 2014, vol. 53, pp. 609-618. DOI: 10.1016/j.asr.2013.11.054.

Ding F., Wan W., Li Q., Zhang R., Song Q., Ning B., Liu L., Zhao B., Xiong B. Comparative climatological study of largescale traveling ionospheric disturbances over North America and China in 2011-2012. J. Geophys. Res.: Space Phys. 2014, vol. 119, pp. 519-529. DOI: 10.1002/2013JA019523.

Dong Z., Jin S. 3-D water vapor tomography in Wuhan from GPS, BDS and GLONASS observations. Remote Sens. 2018, vol. 10, no. 1, 62. DOI: 10.3390/rs10010062.

Dow J.M., Neilan R.E., Rizos C. The International GNSS Service in a changing landscape of Global Navigation Satellite Systems. J. Geodesy. 2009, vol. 83, pp. 191-198. DOI: $10.1007 /$ s0019000803003.

Gulyaeva T.L., Stanislawska I. Derivation of a planetary ionospheric storm index. Ann. Geophys. 2008, vol. 26, pp. 2645-2648. DOI: 10.5194/angeo-26-2645-2008.

Hernández-Pajares M., Juan J.M., Sanz J., Orus R., GarciaRigo A., Feltens J., Komjathy A., Schaer S.C., Krankowski A. The IGS VTEC maps: a reliable source of ionospheric information since 1998. J. Geodesy. 2009, vol. 83, no. 3-4. pp. 263275. DOI: $10.1007 / \mathrm{s} 00190-008-0266-1$.

Hofmann-Wellenhof B., Lichtenegger H., Wasle E. GNSSGlobal Navigation Satellite Systems. Springer, 2008. 531 p. DOI: 10.1007/978-3-211-73017-1.

Jakowski N., Beniguel Y., De Franceschi G., Pajares M.H., Jacobsen K.S., Stanislawska I., Tomasik L., Warnant R., Wautelet G. Monitoring, tracking and forecasting ionospheric perturbations using GNSS techniques. J. Space Weather and Space Climate. 2012a, vol. 2, A22. DOI: 10.1051/swsc/2012022.

Jakowski N., Borries C., Wilken V. Introducing a Disturbance Ionosphere Index (DIX). Radio Sci. 2012b, vol. 47, RS0L14. DOI: 10.1029/2011RS004939.

Jayachandran P.T., Langley R.B., MacDougall J.W., Mushini S.C., Pokhotelov D., Hamza A.M., Mann I.R., Milling D.K., Kale Z.C., Chadwick R., Kelly T., Danskin D.W., Carrano C.S. The Canadian High Arctic Ionospheric Network (CHAIN). Radio Sci. 2009, vol. 44, RS0A03. DOI: 10.1029/ 2008RS004046.

Jin S., Occhipinti G., Jin R. GNSS ionospheric seismology: Recent observation evidences and characteristics. Earth Sci. Rev. 2015, vol. 147, pp. 54-64. DOI: 10.1016/j.earscirev. 2015.05.003.

Juan J.M., Sanz J., Rovira-Garcia A., González-Casado G., Ibáñez D., Perez R.O. AATR an ionospheric activity indicator specifically based on GNSS measurements. J. Space Weather and Space Climate. 2018, vol. 8, A14. DOI: 10.1051/swsc/2017044.

Kunitsyn V., Kurbatov G., Yasyukevich Yu., Padokhin A. Investigation of SBAS L1/L5 signals and their application to the ionospheric TEC studies. Geoscience and Remote Sensing Lett. 2015, vol. 12, no. 3, pp. 547-551. DOI: 10.1109/LGRS. 2014.2350037.

Kunitsyn V.E., Padokhin A.M., Kurbatov G.A., Yasyukevich Yu.V., Morozov Yu.V. Ionospheric TEC estimation with the signals of various geostationary navigational satellites. GPS Solutions. 2016, vol. 20, no. 4, pp. 877-884. DOI: $10.1007 / \mathrm{s} 10291-015-0500-2$.

Lanyi G.E., Roth T. A comparison of mapped and measured total ionospheric electron content using global positioning system and beacon satellite observations. Radio Sci. 1988, vol. 23, no. 4, pp. 483-492. DOI: 10.1029/rs023 i004p00483.

Larson K.M., Nievinski F.G. GPS snow sensing: results from the EarthScope Plate Boundary Observatory. GPS Solutions. 2013, vol. 17, pp. 41-52. DOI: 10.1007/s10291-012-0259-7.

Löfgren J.S., Haas R., Johansson J.M. Monitoring coastal sea level using reflected GNSS signals. Adv. Space Res. 2011, vol. 47, no. 2, pp. 213-220. DOI: 10.1016/j.asr.2010.08.015.

Lukhnev A.V., San'kov V.A., Miroshnichenko A.I., Ashurkov S.V., Calais E. GPS rotation and strain rates in the Baikal-Mongolia region. Russian Geology and Geophysics. 2010, vol. 51, no. 7, pp. 785-793. DOI: 10.1016/j.rgg.2010.06.006.

Lukhneva O.F., Dembelov M.G., Lukhnev A.V. Determination of atmospheric water content from meteorological and GPS data. Geodinamika i tektonofizika [Geodynamics \& Tectonophysics]. 2016, vol. 7, no. 4, pp. 545-553. DOI: 10.5800/ GT-2016-7-4-0222. (In Russian).

Mannucci A.J., Wilson B.D., Yuan D.N., Ho C.M., Lindqwister U.J., Runge T.F. A global mapping technique for GPS-derived ionospheric TEC measurements. Radio Sci. 1998, vol. 33, no. 3, pp. 565-582. DOI: 10.1029/97RS02707.

Mazzotti S., Dragert H., Henton J., Schmidt M., Hyndman R., James T., Lu Y., Craymer M. Current tectonics of northern Cascadia from a decade of GPS measurements. J. Geophys. Res. 2003, vol. 108, no. B12, 2554. DOI: 10.1029/2003JB002653.

Mitchell C.N., Spencer P.S.J. A three-dimensional timedependent algorithm for ionospheric imaging using GPS. Ann. Geophys. 2003, vol. 46, no. 4, pp. 687-696. DOI: 10.4401/ag4373.

Mitchell C.N., Alfonsi L., De Franceschi G., Lester M., Romano V., Wernik A.W. GPS TEC and scintillation measurements from the polar ionosphere during the October 2003 storm. Geophys Res Lett. 2005, vol. 32, L12S03. DOI: 10.1029/ 2004GL021644.

Nesterov I.A., Kunitsyn V.E. GNSS radio tomography of the ionosphere: The problem with essentially incomplete data. $A d v$. Space Res. 2011, vol. 47, no. 10, pp. 1789-1803. DOI: 10.1016/ j.asr.2010.11.034.

Nesterov I.A., Andreeva E.S., Padokhin A.M., Tumanova Yu.S., Nazarenko M.O. Ionospheric perturbation indices based on the low- and high-orbiting satellite radio tomography data. GPS Solutions. 2017 , vol. 21, no. 4, pp. 16791694. DOI: 10.1007/s10291-017-0646-1.

Olemskoy S.V. Implementating the project «National Heliogeophysical Center of RAS» project development. Scientific report at Extended Meeting of SB RAS Presidium on December 21, 2017. Available from: https://www.sbras.ru/ files/files/prezidium20171221/1_olemskoy.pdf (accessed October 1, 2018). [In Russian].

Otsuka Y., Suzuki K., Nakagawa S., Nishioka M., Shiokawa K., Tsugawa T. GPS observations of medium-scale traveling ionospheric disturbances over Europe. Ann. Geophys. 2013, vol. 31, no. 2, pp. 163-172. DOI: 10.5194/angeo-31-163-2013.

Ovodenko V.B., Trekin V.V., Korenkova N.A., Klimenko M.V. Investigating range error compensation in UHF radar through IRI-2007 real-time updating: Preliminary results. Adv. Space Res. 2015, vol. 56, no. 5, pp. 900906. DOI: 10.1016/j.asr.2015.05.017.

Padokhin A.M., Kurbatov G.A., Andreeva E.S., Nesterov I.A., Nazarenko M.O., Berbeneva N.A., Karlysheva A.V. Estimation of sea level variations with GPS/GLONASS-reflectometry technique. Proc. of PIE. 2017, vol. 104667J: $23^{\text {rd }}$ International Symposium on Atmospheric and Ocean Optics: Atmospheric Physics. DOI: 10.1117/12.2288741.

Perevalova N.P., Shestakov N.V., Voeykov S.V., Takahashi H., Guojie M. Ionospheric disturbances in the vicinity of the Chelyabinsk meteoroid explosive disruption as inferred from dense GPS observations. Geophys. Res. Lett. 2015, vol. 42, pp. 6535-6543. DOI: 10.1002/2015GL064792.

Pi X., Mannucci A.J., Lindqwister U.J., Ho C.M. Monitoring of global ionospheric irregularities using the worldwide GPS network. Geophys. Res. Lett. 1997, vol. 24, pp. 2283-2286. DOI: 10.1029/97GL02273.

Priego E., Jones J., Porres M.J., Seco A. Monitoring water vapour with GNSS during a heavy rainfall event in the Spanish Mediterranean area, Geomatics. Natural Hazards and Risk. 
2017, vol. 8, no. 2, pp. 282-294. DOI: 10.1080/19475 705.2016.1201150

Ruffini G., Flores A., Rius A. GPS tomography of the ionospheric electron content with a correlation functional IEEE Transactions on Geoscience and Remote Sensing. 1998, vol. 36, no. 1, pp. 143-153. DOI: 10.1109/36.655324.

Sankov V.A., Lukhnev A.V., Miroshnitchenko A.I., Dobrynina A.A., Ashurkov S.V., Byzov L.M., Dembelov M.G., Calais E., Déverchère J. Contemporary horizontal movements and seismicity of the south Baikal basin (Baikal rift system). Izvestiya, Physics of the Solid Earth. 2014, vol. 50, no. 6, pp. 785-794. DOI: 10.1134/S106935131406007X.

Segall P., Davis J.L. GPS applications for geodynamics and earthquake studies. Ann. Rev. Earth and Planetary Sci. 1997, vol. 25, pp. 301-336. DOI: 10.1146/annurev.earth.25.1.301.

Schaer S., Beutler G., Rothacher M. Mapping and predicting the ionosphere. Proc. IGS AC Workshop, Darmstadt, Germany, February 9-11, 1998, pp. 307-320.

Schunk R.W., Scherliess L., Sojka J.J., Thompson D. Global Assimilation of Ionospheric Measurements (GAIM). $R a$ dio Sci. 2004, vol. 39, RS1S02. DOI: 10.1029/2002RS002794.

Shanmugam S., Jones J., MacAulay A., van Dierendonck A.J. Evolution to Modernized GNSS Ionospheric Scintillation and TEC Monitoring. IEEE/ION PLANS 2012 - April 24-26, Myrtle Beach, SC, Session B2A. 2012. Available from: http://www.novatel.com/assets/Documents/Papers/PID236303 3.pdf (accessed October 1, 2018).

Shestakov N.V., Gerasimenko M.D., Takahashi H., Kasahara M., Bormotov V.A., Bykov V.G., Kolomiets A.G., Gerasimov G.N., Vasilenko N.F., Prytkov A.S. Present tectonics of the southeast of Russia as seen from GPS observations. Geophys. J. International. 2011, vol. 184, no. 2, pp. 529-540. DOI: 10.1111/j.1365-246X.2010.04871.x.

Solomentsev D., Khattatov B., Codrescu M., Titov A., Yudin V., Khattatov V., Ionosphere state and parameter estimation using the Ensemble Square Root Filter and the global three-dimensional first-principle model. Space Weather. 2012, vol. 10, S07004. DOI: 10.1029/2012SW000777.

Sorokin A.A., Korolev S.P., Shestakov N.V., Malkovsky S.I., Tsoy G.I., Pupatenko V.V. Work administration with Global Navigation Satellite System data for complex study of modern geodynamic processes in the south of Far East of Russia. Sovremennye problemy distantsionnogo zondirovaniya Zemli iz kosmosa [Current Problems in Remote Sensing of the Earth from Space]. 2017, vol. 14, no. 3, pp. 158-172. DOI: 10.21046/ 20707401-2017-14-3-158-172. (In Russian).

Tsugawa T., Nishioka M., Ishii M., Hozumi K., Saito S., Shinbori A., Otsuka Y., Saito A., Buhari S., Abdullah M., Supnithi P. Total Electron Content Observations by Dense Regional and Worldwide International Networks of GNSS. $J$. Disaster Res. 2018, vol. 13, no. 3, pp. 535-545. DOI: 10.20965/ jdr.2018.p0535.

Voeykov S.V., Berngardt O.I., Shestakov N.V. Use of the index of TEC vertical variation disturbance in studying ionospheric effects of the Chelyabinsk meteorite. Geomagnetism and Aeronomy. 2016, vol. 56, no. 2, pp. 219-228. DOI: 10.1134/ S0016793216020122.

Yasyukevich Yu.V., Mylnikova A.A., Ivanov V.B. Estimating the absolute total electron content based on single-frequency satellite radio navigation GPS/GLONASS data. Solar-Terr. Phys. 2017a, vol. 3, no. 1, pp. 128-137. DOI: 10.12737/article_58 f972906c64a5.33470182.

Yasyukevich Yu.V., Ovodenko V.B., Mylnikova A.A., Zhivetiev I.V., Vesnin A.M., Edemskiy I.K., Kotova D.S. Methods of compensation of ionospheric component error of radio communication systems using GPS/GLONASS total electron content data. Vestnik Povolzhskogo gosudarstvennogo tekhnologicheskogo universiteta. Ser. Radiotekhnicheskie $i$ infokommunikatsionnye sistemy [Bull. of Volga State University of Technology. Ser. Radio Engineering and Infocommunication Systems]. 2017b, vol. 2, no. 34, pp. 19-31. DOI: 10.15350/2306-2819.2017.2.19. (In Russian).]

Yasyukevich Yu.V., Zhivetiev I.V., Kiselev A.V., Edemskiy I.K., Syrovatsky S.V., Shabalin A.S., Vesnin A.M. Tool for Creating Maps of GNSS Total Electron Content. Proc. Progress in Electromagnetics Research Symposium. Toyama, Japan, 1-4 August, 2018, 180330063056

Yeh K.C., Liu C.H. Radio wave scintillation in the ionosphere. Proc. of IEEE. 1982, vol. 70, no. 4, pp. 324-360. DOI: 10.1109/PROC.1982.12313.

Zhou F., Dong D., Li W., Jiang X., Wickert J., Schuh H. GAMP: An open-source software of multi-GNSS precise point positioning using undifferenced and uncombined observations. GPS Solutions. 2018, vol. 22, 33. DOI: 10.1007/s10291-0180699-9.

Zolesi B., Belehaki A., Tsagouri I., Cander Lj.R. Realtime updating of the Simplified Ionospheric Regional Model for operational applications. Radio Sci. 2004, vol. 39, no. 2. RS2011. DOI: 10.1029/2003RS002936.

URL: http://www.unavco.org (accessed October 1, 2018).

URL: ftp://terras.gsi.go.jp/data (accessed October 1, 2018

URL: ftp://nfs.kasi.re.kr/gps/data/daily (accessed Octobes 2018).

URL: ftp://ftp.sonel.org/gps/data (accessed October 1, 2018)

URL: ftp://ftp.trignet.co.za (accessed October 1, 2018). 2018).

URL: https://hive.geosystems.aero (accessed October 1,

URL: http://smartnet-ru.com (accessed October 1, 2018).

URL: https://eft-cors.ru (accessed October 1, 2018).

URL: http://rtknet.ru (accessed October 1, 2018).

URL: https://simurg.iszf.irk.ru (accessed October 1, 2018).

URL: http://ckp-rf.ru/ckp/3056 (accessed October 1, 2018). 2018).

URL: http://omniweb.gsfc.nasa.gov (accessed October 1,

How to cite this article

Yasyukevich Yu.V., Vesnin A.M., Perevalova N.P. SibNet Siberian Global Navigation Satellite System Network: Current state. SolarTerrestrial Physics. 2018. Vol. 4. Iss. 4. P. 63-72. DOI: 10.12737/stp44201809. 